\title{
Self-medication and adherence to drug treatment: assessment of participants of the Universidade do Envelhecer (the University of Aging) program
}

Antonio Leonardo de Freitas Garcia

Andréia Naomi Madoz Kaya ${ }^{2}$

Eduardo Antonio Ferreira ${ }^{3}$

Eliana Fortes Gris ${ }^{4}$

Dayani Galato ${ }^{5}$

Abstract

Objectives: to evaluate the use of medication (for continuous use and self-medication) and adherence to treatment among elderly and non-elderly participants of the Universidade do Envelhecer (UniSer). Method: an observational, quantitative and cross-sectional study, using the interview technique, was carried out at UniSer with 215 subjects. A structured instrument was used for the collection of sociodemographic variables and self-medication data. The 1986 Morisky-Green-Levine Scale (MGL) and the Brief Medication Questionnaire (BMQ) regimen screening tool were used to assess adherence. Descriptive analyzes of the data were performed, and the chi-squared Test and Fisher's Exact Test were applied to evaluate the association between variables of interest. Results: of the participants, 127 (59.1\%) were elderly (< 60 years old), of whom 81.9\% were women. Regarding selfmedication, $22.9 \%$ of elderly and $21.7 \%$ of non-elderly persons practiced it in the previous seven days $(p=0.848)$, even if they considered it dangerous $(p=0.472$ ). A total of $45.8 \%$ of the elderly and $55.6 \%$ of the non-elderly irrationally self-medicated within the analyzed period, while $76.4 \%$ of the elderly and $64.8 \%$ of the non-elderly used medications of continuous use ( $p=0.063$ ). A total of $78.8 \%$ of the elderly and $76.1 \%$ of the non-elderly were not adherent to treatment $(p=0.719)$ according to the MGL scale, while the BMQ Regimen Screen found that $36.7 \%$ of the elderly and $41.1 \%$ of the non-elderly were not adherent ( $p=0.595)$. Conclusion: these findings demonstrate that there were no significant differences between the groups studied and health education actions should be carried out with an emphasis on guidelines on adherence and the rational use of medicines.

\footnotetext{
Universidade de Brasília, Faculdade de Ceilândia, Programa de Pós-graduação em Ciências e Tecnologias em Saúde. Grupo de Pesquisa em Acesso aos Medicamentos e Uso Responsável - AMUR, Ceilândia, Brasília, Brasil.

2 Universidade de Brasília, Faculdade de Ceilândia, Curso de Farmácia - AMUR. Ceilândia, Brasília, Brasil. Universidade de Brasília, Faculdade de Ceilândia, Curso de Farmácia. Ceilândia, Brasília, Brasil.

4 Universidade de Brasília, Faculdade de Ceilândia, Curso de Farmácia e Programa de Pós-Graduação em Ciências e Tecnologias em Saúde. Ceilândia, Brasília, Brasil.

5 Universidade de Brasília, Faculdade de Ceilândia, Curso de Farmácia e Programa de Pós-Graduação em Ciências e Tecnologias em Saúde - AMUR. Ceilândia, Brasília, Brasil.

Correspondence

Dayani Galato

dayani.galato@gmail.com
}

Keywords: Aging. Drug Utilization. Self Medication. Treatment Adherence and Compliance. Chronic Disease. 


\section{INTRODUCTION}

Aging brings an increase in the prevalence of chronic diseases and the application of medications, especially continuous use drugs ${ }^{1-3}$. In addition to taking such medications, adults and elderly persons practice self-medication as a form of self-care. This is defined as the selection and use of medications for the treatment of diseases and symptoms that affect the user, without prescription or monitoring by a qualified professional (doctor or dentist) ${ }^{4-6}$.

Some factors may affect this practice, such as different forms of access to health services, the degree of information available about the medications, as well as the influence of friends, family members, drug advertisements and medicines leftover from previous treatments ${ }^{7}$. Disadvantages related to self-medication can be found in all strata of the population, but especially among the elderly. These include unnecessary expense, delays in diagnoses, potential risks of intoxication and drug interactions, and bacterial resistance?

On the other hand, it is important to evaluate adherence to drug treatment involving continuous use medications, as this is considered to be one of the main determinants of the effectiveness of pharmacotherapy. Adherence is defined as the degree of concordance between the behavior of the user and the instructions of the doctor or other health professional ${ }^{8,9}$

The reduced effectiveness of treatments can be explained by several factors, such as barriers of access to the health system, financial difficulties, adverse effects and non-adherence. This problem may vary within population groups, and geographical location (distance that individuals have to travel to access health services), lifestyle (such as eating habits and physical activity), and health conditions may interfere directly with adherence ${ }^{10}$.

Interdisciplinary actions are important and can contribute to the rational use of medication. In this context, strategies that focus on health care can be beneficial to improving the quality of life of the elderly population. These strategies include projects linked to health and social welfare departments, such as groups for the elderly, and those linked to universities such as the Universidades Abertas à Terceira Idade (Universities for the Third Age) (UnATI) and other university extension programs such as the Universidade do Envelhecer (University of Aging) (UniSer). Therefore, understanding the health and medication profile of the participants of strategies like these is important for the definition of educational actions that promote the rational use of medication.

The present study therefore sought to evaluate the use of drugs taken in a continuous and selfmedicated manner among elderly and non-elderly participants of the University of Aging (UniSer), as well as to evaluate the adherence to treatment with continuous medication of these two groups.

\section{METHOD}

An observational, quantitative, cross-sectional type study using an interview technique was applied. The study was carried out in the Distrito Federal (DF), in an extension program of the Universidade de Brasília (UnB), entitled the Universidade do Envelhecer (the University of Aging) (UniSer). This program proposes actions that encourage the promotion of citizenship and health among the elderly and adults over 45 years of age. The intention of this program is to promote an education that broadens a sense of quality of life, adding knowledge, experience and the constant participation of the students in the promotion of healthy aging ${ }^{11}$.

The total number of students enrolled in the extension program in 2017 (420) was used for sample calculation. A prevalence of outcome of $50 \%$, a $95 \%$ confidence interval and a 5\% sample error were considered, resulting in a minimum sample of 201 subjects. The sample was selected for convenience, and participants from all the centers of the extension program were included until at least the minimum estimated sample size was achieved. Participation in the extension program was used as an inclusion criterion. The exclusion criteria were the participant's inability to respond to questions relating to the use of medication or the interruption of the interview before completion. Participants aged between 45 and 59 years were considered to be non-elderly, while those aged 60 years or over were considered elderly. 
Data collection was carried out from April to December 2017, at the centers where the classes of the extension program in Brasília took place (in the Administrative Regions of Ceilândia, Taguatinga, Candangolândia, Riacho Fundo I, Estrutural and Plano Piloto). The interviews were conducted by groups of calibrated interviewers who underwent training based on a manual and regular meetings to resolve any questions that arose during the procedure. All the completed interview scripts were checked and the database was created. Where inconsistencies or incomplete data were identified the interviewee was contacted by telephone.

The interview script allowed the collection of a range of variables. The sociodemographic variables collected were gender, age, city of origin, ethnicity/ color (self-declared by respondents), marital status, schooling, profession, and family income. The variables related to health were reported health problems, health insurance and whether any of the participants had a relative who was a health professional. Variables related to medication were also considered, namely continuous use medicines, adoption of self-medication, adherence to treatment and access to medication (form of acquisition of continuous use medication).

To analyze the rationality of self-medication, in this case understood as adequacy, the following criteria were adopted: the medicine used in the self-medication should be exempt from medical prescription (EMP); the health problem must be selflimiting (acute); and the duration of the symptoms shorter than 15 days. Practices that met all the above criteria were considered rational.

For the results of self-medication, the interviewees were asked to report whether the health problem had been resolved after the adoption of the practice. The problem was considered resolved when so perceived by the interviewee and when he/she related the improvement to the self-medication.

Home-made medicines, teas, and herbal and homeopathic medicines were not considered self-medication in the present study. During the interviews the participants were informed about the meaning of self-medication and its variations, from going to a health establishment and buying a medicine without a prescription, to taking medicine on the recommendation of friends or family, as well as using leftovers from previous treatments. This concept was explained to all the interviewees before they answered questions related to the practice. For the analysis of self-medication a recall period of seven days prior to the interview was applied as a way of minimizing memory bias.

Medications of continuous use were defined as those that the participants used every day, or almost every day, with no predicted date for the end of the treatment. When participants forgot the medications used, whether continuous use or self-medication, they were informed that they would be contacted later by telephone to collect this information.

the 1986 Morisky-Green-Levine Adherence Scale (MGL) ${ }^{12}$, and the Brief Medication Questionnaire (BMQ) regimen domain ${ }^{13}$, previously validated in other studies, were used to obtain data related to treatment adherence.

The MGL scale used was translated from the version published in 1986, recommended by Dr. Donald Morisky and notable for the simplicity of its application (as it consists of only four questions) ${ }^{10}$. The scale indicates that inadequate medication use occurs for one or all of the following reasons: carelessness, forgetfulness, and the discontinuation of treatment when feeling better or worse. In the present study scores of YES $=1$ point and $\mathrm{NO}$ $=0$ point were considered. If the answers to the four questions were $\mathrm{NO}$ the score was 0 and the participant was considered "adherent to treatment medications". Those participants who scored between 1 and 4 were considered "non-adherent"12.

The BMQ is made up of three domains: Regimen, Belief and Recall. For the present study, the Regimen domain was adopted as an instrument for the evaluation of adherence, as it evaluates the behavior of the participants in relation to the treatment ${ }^{13,14}$.

Prior to data collection, the instrument used in the study was tested in a pilot study with 50 participants to verify the adequacy of the questions and to train the interviewers. Only minor adjustments were necessary in the order of the questions and in the form of approach, meaning the exclusion of the pilot data in the study was not required. 
The database was constructed in the EpiData 3.0 program and later analyzed in the SPSS 23.0 and EpiInfo 7.0 programs. Descriptive analyzes of the data were performed, and the prevalences related to the profile of the participants were estimated with a 95\% confidence interval (CI). Bivariate analysis was also performed using a chi-squared test to evaluate the association between the categorical variables, and the prevalence ratios were presented. When necessary, Fisher's exact test was used. A level of significance of $5 \%(\mathrm{p}<0.05)$ was applied.

The present study was approved by the Research Ethics Committee of the Faculdade de Ceilândia (FCE/UnB), under approval number 1.985.490, and complied with the requirements for studies involving humans of National Health Council Resolution $n^{\circ} 466 / 2012$ and the Declaration of
Helsinki. The participants signed a Free and Informed Consent Form (FICF).

\section{RESULTS}

Of the 420 participants of the project, 215 were included in this study and there were no exclusions. It was observed that the interviewees were predominantly female $(189 ; 87.9 \%)$, with a mean age of 61.3 years (+8.6); non-white (139; 65.6\%), with low levels of schooling ( $<12$ years of schooling) $(150 ; 69.9 \%)$ and had a family income of over three times the minimum wage $(121,56.3 \%)$. The majority of respondents were retired $(121 ; 56,3 \%)$. Of the total sample, $88(40.9 \%)$ were non-elderly, with a mean age of 53.6 years $(+4.95)$ and $127(59.1 \%)$ were elderly, with a mean age of 66.7 years $(+6.23)$. Table 1 shows the data related to the sociodemographic variables of the UniSer participants.

Table 1. Sociodemographic profile of participants of UniSer. Brasília, DF, 2017.

\begin{tabular}{|c|c|c|}
\hline Variables & $\mathrm{n}(\%)$ & $\mathrm{CI} 95 \%$ \%** \\
\hline \multicolumn{3}{|l|}{ Gender $(n=215)$} \\
\hline Female & $189(87.9)$ & 82.9-91.6 \\
\hline Male & $26(12.1)$ & $8.4-17.1$ \\
\hline \multicolumn{3}{|l|}{ Ethnicity/Skin color (self-declared) $(n=211)$} \\
\hline Non-white & $139(65.8)$ & $59.2-71.9$ \\
\hline White & $72(34.2)$ & $28.1-40.7$ \\
\hline \multicolumn{3}{|l|}{ Marital status $(\mathrm{n}=213)$} \\
\hline Without partner & $123(57.7)$ & $51.0-64.2$ \\
\hline Lives with partner & $90(42.3)$ & $35.8-49.0$ \\
\hline \multicolumn{3}{|l|}{ Schooling $(\mathrm{n}=215)$} \\
\hline Less schooling (<12 years) & $150(69.9)$ & $63.3-75.5$ \\
\hline More schooling ( $>12$ years) & $65(30.1)$ & $24.5-36.7$ \\
\hline \multicolumn{3}{|l|}{ Place of Origin $(\mathrm{n}=215)$} \\
\hline Central (Plano Piloto and neighboring regions)* & $20(9.3)$ & $6.1-13.9$ \\
\hline Periphery (Distant from Plano Piloto) & $195(90.7)$ & $86.1-93.9$ \\
\hline \multicolumn{3}{|l|}{ Family Income** $(\mathrm{n}=215)$} \\
\hline Up to three times minimum wage & $94(43.7)$ & $37.2-50.4$ \\
\hline Over three times minimum wage & $121(56.3)$ & $49.6-62.7$ \\
\hline \multicolumn{3}{|l|}{ Occupation $(n=215)$} \\
\hline Retired & $121(56.3)$ & $49.6-62.7$ \\
\hline Without pension & $94(43.7)$ & $37.2-50.4$ \\
\hline \multicolumn{3}{|l|}{ Has health insurance } \\
\hline Yes & $111(51.6)$ & $45.0-58.2$ \\
\hline No & $104(48.4)$ & $41.8-55.0$ \\
\hline \multicolumn{3}{|l|}{ Has relative trained in area of health } \\
\hline Yes & $135(62.8)$ & $56.2-69.0$ \\
\hline No & $80(37.2)$ & $31.0-43.8$ \\
\hline
\end{tabular}

*The Plano Piloto and neighboring regions such as Park Way, Lago Sul and Norte and Sudoeste are considered the most affluent regions of the DF; ${ }^{* *}$ Minimum wage in 2017 ( $\left.\mathrm{R} \$ 937.00=\mathrm{U} \$ 282.22\right) ;{ }^{* * *} \mathrm{CI} 95 \%$ : Confidence interval. 
The taking of continuous use medications was reported by 154 (71.6\%, CI: $65.3 \%-77.2 \%)$ of those interviewed, of whom 83 (53.9\%, CI: 46.0\%-61.6\%) acquired their medicines with their own resources, 52 (33.8\%, CI: $26.8 \%-41.5 \%)$ from health units of the public system of the Distrito Federal and 19 (12.3\%, CI: 8.0\%-18.5\%) from the Farmácia Popular (the Popular Pharmacy) program.
The prevalence of those who had practiced self-medication at some stage in their life in the interviewed group was 188 students $(87.4 \%, \mathrm{CI}$ : $82.3 \%-91.2 \%)$. Of these, $42(22.3 \%$, CI: $17.0 \%-$ $28.8 \%$ ) had practiced self-medication in the seven days prior to the interview. The variables analyzed in the comparison between the elderly and non-elderly of UniSer for self-medication are shown in Table 2.

Table 2. Analysis of practice of self-medication among elderly and non-elderly participants of UniSer. Brasília, DF, 2017.

\begin{tabular}{|c|c|c|c|c|}
\hline Variables & $\begin{array}{l}\text { Non-elderly } \\
\mathrm{n}(\%)\end{array}$ & $\begin{array}{l}\text { Elderly } \\
\mathrm{n}(\%)\end{array}$ & $\mathrm{PR} *(\mathrm{CI} 95 \%)$ & $p^{* *}$ \\
\hline Consider self-medication dangerous $(\mathrm{n}=215)$ & & & & 0.472 \\
\hline Yes & $85(96.6)$ & $120(94.5)$ & $1.022(0.965-1.83)$ & \\
\hline No & $3(3.4)$ & $7 \quad(5.5)$ & 1.000 & \\
\hline Self-medication $(\mathrm{n}=188)$ & & & & 0.848 \\
\hline Yes & $18(21.7)$ & $24(22.9)$ & $0.949(0.553-1.627)$ & \\
\hline No & $65(78.3)$ & $81(77.1)$ & 1.000 & \\
\hline Result of self-medication $(n=42)$ & & & & $0.122^{* * *}$ \\
\hline Health problem resolved & $18(100.0)$ & $20(83.3)$ & $1.200(1.003-1.435)$ & \\
\hline Health problem not resolved/continues & $0 \quad(0.0)$ & $4(16.7)$ & 1.000 & \\
\hline Adequacy of self-medication $(n=42)$ & & & & 0.533 \\
\hline Rational self-medication & $8(44.4)$ & $13(54.2)$ & $0.821(0.425-1.547)$ & \\
\hline Irrational self-medication & $10(55.6)$ & $11(45.8)$ & 1.000 & \\
\hline
\end{tabular}

*Prevalence ratio; ${ }^{* *} p<0.05$ : Chi-squared; ${ }^{* *}$ Calculated by Fisher's Exact Test.

No significant differences between the age groups were observed, with a tendency for the use of continuous use medications and reports of health problems to increase among the elderly, as can be observed in Table 3.

There was no significant difference between the age groups in terms of adherence, with both demonstrating limited adherence to treatment with continuous use medications. According to the MGL Scale, 67 elderly ( $n=85 ; 78.8 \%$ ) and 35 non-elderly ( $n=46 ; 76.1 \%$ ) persons were considered non-adherent to treatment. For the BMQ regimen domain, 33 elderly ( $n=90,36.7 \%$ ) and 23 non-elderly ( $n=56$; $41.1 \%$ ) persons were also considered non-adherent to treatment (Table 3). 
Table 3. Comparison of the reports of health problems and continuous use of medications among elderly and non-elderly participants of UniSer. Brasília, DF, 2017.

\begin{tabular}{|c|c|c|c|c|}
\hline Variables & $\begin{array}{l}\text { Non-elderly } \\
\mathrm{n}(\%)\end{array}$ & $\begin{array}{l}\text { Elderly } \\
\mathrm{n}(\%)\end{array}$ & PR* (CI95\%) & $p^{* *}$ \\
\hline Reports of health problems ( $\mathrm{n}=215)$ & & & & 0.064 \\
\hline Yes & $61(69.3)$ & $102(80.3)$ & $0.863(0.733-1.016)$ & \\
\hline No & $27(30.7)$ & $25(19.7)$ & 1.000 & \\
\hline Use of continuous use medication $(n=215)$ & & & & 0.063 \\
\hline Yes & $57(64.8)$ & $97(76.4)$ & $0.848(0.707-1.017)$ & \\
\hline No & $31(35.2)$ & $30(23.6)$ & 1.000 & \\
\hline \multicolumn{5}{|l|}{ Adherence to treatment with medication } \\
\hline MGL Scale (1986) $(\mathrm{n}=131)$ & & & & 0.719 \\
\hline Adherence & $11(23.9)$ & $18(21.2)$ & $1.129(0.584-2.182)$ & \\
\hline Non-adherence & $35(76.1)$ & $67(78.8)$ & 1.000 & \\
\hline BMQ (Regimen Domain) ( $\mathrm{n}=146)$ & & & & 0.595 \\
\hline Adherence & $33(58.9)$ & $57(63.3)$ & $0.930(0.711-1.128)$ & \\
\hline Non-adherence & $23(41.1)$ & $33(36.7)$ & 1.000 & \\
\hline
\end{tabular}

*Prevalance ratio; ${ }^{* *} p<0.05:$ Chi-squared.

\section{DISCUSSION}

While is increasingly common to begin studying (and to return to one's studies) in adulthood, there is little information about the health of this population. The University of Aging (UniSer), while an extension course (with a timetable of 720 hours) rather than a university, has a different objective from other such projects in Brazil, like the Open Universities for the Third Age (UnATI), as it offers training for adults, especially among the elderly. In this context, the present study is important in terms of trying to understand the behavior related to the use of medication among this population.

The present study found that participants of UniSer are mostly women, non-white (including those with brown, black and "yellow" skin-colours and indigenous peoples, among others), with low levels of schooling, and were retirees, data which is consistent with other Brazilian studies ${ }^{15-19}$.

In Brazil, 38.3\% of elderly persons have a family income of between half the minimum wage and the minimum wage ${ }^{20}$. The findings of the present study, however, were different. One of the possible explanations for this is that the Distrito Federal has the highest Human Development Index (HDI) of all the federative units of Brazil, and the greatest difference between the HDI of the DF and the other states is found in the Income component ${ }^{21}$.
Moreover, more than half of the participants did not have a partner, as other studies have found ${ }^{17,19}$. Having a partner becomes important in health care, and often caregivers are the spouses of the patient. Their involvement can contribute to the administration of medicines and also the monitoring of health services ${ }^{1,22}$.

In relation to the acquisition of continuous use medications, it was observed that most of the interviewees acquired these with their own resources. This may be a reflection of the quality of primary care in the Distrito Federal, one of the most problematic in the country in terms of state capitals ${ }^{23}$, as well as the need for up-to-date medical prescriptions for both public-sector procurement and through the Farmácia Popular (Popular Pharmacy) program. In addition, it should be pointed out that the list of medicines is restricted in both the aforementioned access points.

No significant differences were found between the groups of elderly and non-elderly participants in the program for the variables used in the comparison of the practice of self-medication. In other words both groups used medication in an inadequate manner, which is a risk to the health of the adults and especially the elderly of UniSer. Low schooling may be one of the identified factors that interferes with self-care. Older, more educated individuals tend to understand the information provided by health 
professionals better, as well as the importance of the rational use of drugs ${ }^{24}$, even if this was not observed in the present study.

Among UniSer participants, $76.4 \%$ of the elderly persons take medications of continuous use. According to the National Survey on the Access, Use and Promotion of the Rational Use of Medication (PNAUM), this figure reaches as high as $95.0 \%$ among the elderly population ${ }^{25}$. Other local studies have shown that these values can range from $75.7 \%$ to $85.5 \%{ }^{17,26}$, findings compatible with the results obtained by the study. The vulnerability of the elderly to adverse effects is high, mainly due to the need to use more than one drug to treat their health problems, in addition to the pharmacokinetic and pharmacodynamic changes that occur with aging itself $^{26}$. In the case of UniSer, it is estimated that healthier elderly persons use the program, which would explain the differences in the prevalence of drug use. Discussions on health education are necessary, especially in relation to self-medication, thus helping to prevent or minimize the adverse effects that the inappropriate use of medicines can cause in the elderly population and also the masking of diseases ${ }^{26}$.

The prevalence of the practice of self-medication at some point in the lives of UniSer participants was $87.4 \%$, while it was practiced in the seven days prior to data collection among $22.3 \%$. Values from $14.9 \%$ to $35.0 \%$ were found in literature 6,27 . The prevalence obtained in the present study is similar to those found by other Brazilian studies. However, there are some methodological differences, such as the seven-day recall period employed, compared to the 15 day period used by other studies, as well as the characteristics of the investigated population (age and income). It should also be noted that selfmedication can increase with higher educational levels and better socioeconomic levels ${ }^{7,28}$. The more an individual acquires knowledge throughout life and improves their financial situation, the more access and confidence they have in relation to selfmedication. However, it is important that this process occurs based on the criteria of the rational use of medicines. It should not be adopted, for example, for chronic problems or with medications sold subject to medical prescription ${ }^{6,25}$.

When considering only the elderly population, a prevalence of $22.9 \%$ was found for self-medication in the previous seven days, which falls within values found in studies specific to this group which provide results ranging from $8.9 \%$ to $70.8 \% 0^{16,29}$. This variation can also be explained by the characteristics of the researched population, the concept of self-medication adopted and the recall period.

Regarding the rationality of the practice of selfmedication, $45.8 \%$ of the elderly who engaged in this practice during the previous seven days did not meet the criteria defined as rational by the study, even though $94.5 \%$ considered it dangerous for their health. Self-medication when practiced in a rational manner can avoid harm to health, as well as unnecessary expenses with self-limiting diseases. However, it is important to be aware of the disadvantages that can arise from self-medication, especially among the elderly population, from the masking of serious diseases to the appearance of adverse reactions (consequently increasing health spending). In addition, there is a risk of drug interactions and intoxications ${ }^{4,6}$. Therefore, selfmedication should be carried out rationally, especially among the elderly population, and must be assisted by trained health professionals, since the risk of the practice is also related to the levels of education and information of users about medications ${ }^{30}$.

In the present study, the prevalence of elderly patients who were nonadherent to treatment with continuous use medications was high. When using the MGL scale, $78.8 \%$ of the interviewees were considered non-adherent, compatible with other results found in previous studies ${ }^{14,31,32}$. According to the World Health Organization (WHO), adherence to treatment with continuous use medications is usually around $50.0 \%$ in developed countries. In developing countries this value may be much lower ${ }^{33}$.

Adherence was also assessed using the BMQ regimen domain, which found that $36.7 \%$ of the elderly did not adhere to treatment. The result obtained was different from that of the MGL scale. Some factors may explain this variation in nonadherence rates, such as cultural differences, health status, and the origin of the population studied ${ }^{10}$, and especially the fact that data collection instruments differ in their questions and contexts, such as the time of evaluation in relation to the use of medicines. The MGL scale considers a longer period, while the BMQ considers data from the previous week, which restricts 
the time period investigated and could minimize memory bias. In addition, a simplified version of the BMQ was used in the question of dosage. A study carried out in Porto Alegre, Rio Grande do Sul, found in a pilot study that the participants of the research could not report the concentrations of the drugs used, thus suggesting the simplification of BMQ regimen domain ${ }^{13}$. Failure in this regard could already be considered non-adherence to treatment. This detail may have contributed to the difference in results between the instruments.

On the other hand, the use of two questionnaires allowed the identification of different behaviors in terms of non-adherence to treatment, allowing a better understanding of the phenomenon under investigation. This allows the creation of health education strategies with this population, in order to improve the use of continuous use medications.

Consequences of non-adherence to treatment with medication include the lack of control of diseases, the increased risk of hospitalizations and increased mortality ${ }^{8,10,14,31,34}$. In other words, this practice involves clinical, social and economic consequences, yet receives little attention. Its evaluation is therefore essential to slow the progression of diseases and avoid the emergence of side effects. In this context, regardless of the questionnaire applied, no significant difference was found between the elderly and the non-elderly groups.

It should be emphasized that health education, including topics on the use of medication and selfcare, should form part of adult education, as well as the training of all health professions, regardless of their relationship with this form of technology.

One limitation of the present study is the fact that most of the information obtained was self-reported, and there is therefore a possibility of memory bias among the participants, as it involves recall evaluation. However, it is important to note that the instruments adopted for the evaluation of adherence are recognized for their validity, and the recall form and period adopted for the determination of self-medication and its context (the adopted concept) are consistent with other works described in literature for this age range.

\section{CONCLUSION}

No significant differences were identified in selfmedication or the continuous use of medication among the groups of elderly and non-elderly participants of the University of Aging program. Similarly, no differences were found between the groups for the rationality of self-medication or adherence to treatment. In this context, the practice of self-medication in the previous seven days was considered irrational. These data are important, as more than half of the participants of the University of Aging are elderly, and more susceptible to the negative effects of self-medication.

The data related to adherence were not adequate, even though two different questionnaires were used for evaluation. Both groups exhibited low adherence to treatment with medications of continuous use, which consequently poses health risks, mainly due to the inefficacy of the use of the medication prescribed for the reported diseases.

Thus, the findings of the present study reinforce the need to educate both adults and the elderly about self-care, either through content related to the practice of self-medication or the use of medications on a continuous basis, with a view to encouraging adherence to treatment to improve the health profile of this population.

\section{REFERENCES}

1. Almeida NA, Reiners AAO, Azevedo RCS, Silva AMC, Cardoso JDC, Souza LC. Prevalência e fatores associados à polifarmácia entre os idosos residentes na comunidade. Rev Bras Geriatr Gerontol. 2017;20(1):143-53.
2. Miranda GMD, Mendes ACG, Silva ALA. O envelhecimento populacional brasileiro: desafios e consequências socais atuais e futuras. Rev Bras Geriatr Gerontol. 2016;19(3):507-19. 
3. World Health Organization. World report on ageing and health. Geneva: WHO; 2015.

4. Fernandes WS, Cembranelli JC. Automedicação e o uso racional de medicamentos: o papel do profissional farmacêutico no combate a essas práticas. Rev Univap. 2015;21(37):5-12.

5. World Health Organization. The role of the pharmacist in self-care and self-medication. Geneva: WHO; 1998.

6. Domingues PHF, Galvão TF, Andrade KRC, Silva MT, Pereira MG. Prevalência e fatores associados à automedicação em adultos no Distrito Federal: estudo transversal de base populacional. Epidemiol Serv Saúde 2017;26(2):319-30.

7. Arrais PSD, Fernandes MEP, Dal Pizzol TS, Ramos LR, Mengue SS, Luiza VL, et al. Prevalência da automedicação no Brasil e fatores associados. Rev Saúde Pública. 2016;50(supl 2):1-11.

8. Tavares NIL, Bertoldi AD, Mengue SS, Arrais PSD, Luiza VL, Oliveira MA, et al. Fatores associados à baixa adesão ao tratamento farmacológico de doenças crônicas no Brasil. Rev Saúde Pública. 2016;50(Supl 2):1-10.

9. Aquino GA, Cruz DT, Silvério MS, Vieira MT, Bastos RR, Leite ICG. Fatores associados à adesão ao tratamento farmacológico em idosos que utilizam medicamento anti-hipertensivo. Rev Bras Geriatr Gerontol. 2017;20(1):116-27.

10. Remondi FA, Cabrera MAS, Souza RKT. Não adesão ao tratamento medicamentoso contínuo: prevalência e determinantes em adultos de 40 anos e mais. Cad Saúde Pública. 2014;30(1):126-36.

11. Universidade do Envelhecer da Universidade de Brasília. Porque envelhecer é um ato de amor [Internet]. Brasília, DF: UNISER; 2018 [acesso em 20 maio 2018]. Disponível em: https://www.uniserunb. com/nosso-projeto

12. Morisky DE, Green LW, Levine DM. Concurrent and predictive validity of a self-reported measure of medication adherence. Med Care. 1986;24(1):67-74.

13. Ben AJ, Neumann CR, Mengue SS. Teste de MoriskyGreen e Brief Medication Questionnaire para avaliar adesão a medicamentos. Rev Saúde Pública. 2012;46(2):279-89.

14. Segundo AFSM. Avaliação do grau de aderência medicamentosa em pacientes com epilepsia [Dissertação]. Pernambuco: Universidade de Pernambuco, Centro de Ciências da Saúde, Universidade Federal de Pernambuco; 2015.

15. Abi-Ackel MM, Lima-Costa MF, Castro-Costa E, Filho AIL. Uso de psicofármacos entre idosos residentes em comunidade: prevalência e fatores associados. Rev Bras Epidemiol. 2017;20(1):57-69.
16. Sales AS, Sales MGS, Casotti CA. Perfil farmacoterapêutico e fatores associados à polifarmácia entre idosos de Aiquara, Bahia, em 2014. Epidemiol Serv Saúde. 2017;26(1):121-32.

17. Neves SJF, Marques APO, Leal MCC, Diniz AS, Medeiros TS, Arruda IKG. Epidemiologia do uso de medicamentos entre idosos em área urbana do Nordeste do Brasil. Rev Saúde Pública. 2013;47(4):759-68.

18. Barroso R, Telles Filho PCP, Pinheiro MLP, Bodevan EC, Pereira Júnior AC, Cambraia RP. Automedicação em idosos de estratégias de Saúde da Família. Rev Enferm UFPE [Internet]. 2017;11(Supl 2):890-7.

19. Ely LS, Engroff P, Guiselli SR, Cardoso GC, Morrone FB, De Carli GA. Uso de anti-inflamatórios e analgésicos por uma população de idosos atendida na estratégia Saúde da Família. Rev Bras Geriatr Gerontol. 2015;18(3):475-85.

20. Instituto Brasileiro de Geografia e Estatística. Síntese de indicadores sociais: uma análise das condições de vida da população brasileira. Rio de Janeiro: IBGE; 2016.

21. Brasília. Secretária de Estado de Saúde do Distrito Federal. Plano distrital de saúde 2016-2019. Brasília, DF: SESDF; 2016.

22. Santos-Orlandi AA, Brito TRP, Ottaviani AC, Zazzetta MS, Gratão ACM, et al. Perfil de idosos que cuidam de outros idosos em contexto de alta vulnerabilidade social. Esc Anna Nery. 2017;21(1):1-8.

23. Sousa MF, Hamann EM. Programa Saúde da Família no Brasil: uma agenda incompleta? Ciênc Saúde Coletiva. 2009;14(Supl 1):1325-35.

24. Neves RG, Duro SMS, Flores TR, Nunes BP, Costa CS, Wendt A, et al. Atenção oferecida aos idosos portadores de hipertensão: Pesquisa Nacional de Saúde, 2013. Cad Saúde Pública. 2017;33(7):1-11.

25. Ramos LR, Tavares NUL, Bertoldi AD, Farias MR, Oliveira MA, Luiza VL, et al. Polifarmácia e polimorbidades em idosos no Brasil: um desafio em saúde pública. Rev Saúde Pública. 2016;50(Supl 2):1-13.

26. Luz EP, Dallepiane LB, Kirchner RM, Silva LAA, Silva FP, Kohler J, et al. Perfil sociodemográfico e hábitos de vida da população idosa de um município da região norte do Rio Grande do Sul, Brasil. Rev Bras Geriatr Gerontol. 2014;17(2):303-14.

27. Domingues PHF, Galvão TF, Andrade KRC, Sá PTT, Silva MT, Pereira MG. Prevalência da automedicação na população adulta do Brasil: revisão sistemática. Rev Saúde Pública. 2015;49:1-9.

28. Schmid B, Bernal R, Silva NN. Automedicação em adultos de baixa renda no município de São Paulo. Rev Saúde Pública. 2010;44(6):1039-45. 
29. Araújo PL, Galato D. Risco de fragilização e uso de medicamentos em idosos residentes em uma localidade do sul de Santa Catarina. Rev Bras Geriatr Gerontol. 2012;15(1):119-26.

30. Prado MAMB, Francisco PMSB, Bastos TF, Barros MBA. Uso de medicamentos prescritos e automedicação em homens. Rev Bras Epidemiol. 2016;19(3):594-608.

31. Girotto E, Andrade SM, Cabrera MAS, Matsuo T. Adesão ao tratamento farmacológico e não farmacológico e fatores associados na atenção primária da hipertensão arterial. Ciênc Saúde Coletiva. 2013;18(6):1763-72.

Received: June 06, 2018

Reviewed: September 17, 2018

Accepted: September 26, 2018
32. Marchi KC, Chagas MHN, Tumas V, Miasso AI, Crippa JAS, Tirapello CR. Adesão à medicação em pacientes com doença de Parkinson atendidos em ambulatório especializado. Ciênc Saúde Coletiva. 2013;18(3):855-62.

33. World Health Organization. Adherence to long-term therapies: evidence for action. Geneva: WHO; 2003.

34. Lutz BH, Miranda VIA, Bertoldi AD. Inadequação do uso de medicamentos entre idosos em Pelotas, RS. Rev Saúde Pública. 2017;51:1-12. 